\title{
Adaptation Tipping Points of a Wetland under a Drying Climate
}

\author{
Amar Nanda ${ }^{1,2}$ (i), Leah Beesley ${ }^{2,3}$, Luca Locatelli ${ }^{4}$, Berry Gersonius ${ }^{2,5}$, Matthew R. Hipsey ${ }^{2,6}$ \\ and Anas Ghadouani ${ }^{1,2, * \text { (iD) }}$ \\ 1 Department of Civil, Environmental \& Mining Engineering, The University of Western Australia, \\ 35 Stirling Highway, M051, Perth 6009 WA, Australia; 21449794@student.uwa.edu.au \\ 2 Cooperative Research Centre for Water Sensitive Cities (CRCWSC), Clayton 3800 VIC, Australia; \\ leah.beesley@uwa.edu.au (L.B.); b.gersonius@un-ihe.org (B.G.); matt.hipsey@uwa.edu.au (M.R.H.) \\ 3 School of Biological Sciences, The University of Western Australia, 35 Stirling Highway, M004, \\ Perth 6009 WA, Australia \\ 4 Department of Environmental Engineering, Technical University of Denmark, 2800 Kongens Lyngby, \\ Denmark; lulo@env.dtu.dk \\ 5 UNESCO-IHE, Westvest 7, 2611 AX Delft, The Netherlands \\ 6 School of Agriculture and Environment, The University of Western Australia, Perth 6009 WA, Australia \\ * Correspondence: anas.ghadouani@uwa.edu.au; Tel.: +61-8-6488-2687
}

Received: 12 January 2018; Accepted: 20 February 2018; Published: 24 February 2018

\begin{abstract}
Wetlands experience considerable alteration to their hydrology, which typically contributes to a decline in their overall ecological integrity. Wetland management strategies aim to repair wetland hydrology and attenuate wetland loss that is associated with climate change. However, decision makers often lack the data needed to support complex social environmental systems models, making it difficult to assess the effectiveness of current or past practices. Adaptation Tipping Points (ATPs) is a policy-oriented method that can be useful in these situations. Here, a modified ATP framework is presented to assess the suitability of ecosystem management when rigorous ecological data are lacking. We define the effectiveness of the wetland management strategy by its ability to maintain sustainable minimum water levels that are required to support ecological processes. These minimum water requirements are defined in water management and environmental policy of the wetland. Here, we trial the method on Forrestdale Lake, a wetland in a region experiencing a markedly drying climate. ATPs were defined by linking key ecological objectives identified by policy documents to threshold values for water depth. We then used long-term hydrologic data (1978-2012) to assess if and when thresholds were breached. We found that from the mid-1990s, declining wetland water depth breached ATPs for the majority of the wetland objectives. We conclude that the wetland management strategy has been ineffective from the mid-1990s, when the region's climate dried markedly. The extent of legislation, policies, and management authorities across different scales and levels of governance need to be understood to adapt ecosystem management strategies. Empirical verification of the ATP assessment is required to validate the suitability of the method. However, in general we consider ATPs to be a useful desktop method to assess the suitability of management when rigorous ecological data are lacking.
\end{abstract}

Keywords: ecosystem; wetland; adaptation tipping points; climate change; management strategy

\section{Introduction}

Ecological systems with high resilience are able to cope with frequent disturbance and remain relatively stable over time, whereas systems with low resilience are likely to transition to altered states, often with reduced function in the wake of disturbance [1]. Systems with low resilience can shift 
between alternative stable states by an incremental change of conditions that induce a catastrophic (reversible) shift or by perturbations that are large enough to move the system to a lower alternative state with reduced functions [2,3]. Social-ecological systems (SES) have interacting components (e.g., political, social, or ecological) and have many functions that depend on feedback mechanisms between processes that take place at multiple scales $[4,5]$.

Ecosystems are managed to maintain their beneficial ecological functions, but can be vulnerable to altered external processes (e.g., climate change); such processes can shift ecosystems to reduced ecological functions [6]. These complex ecosystems, under the influence of drivers of ecological and social processes, can change and then often display nonlinear behavior with prolonged periods of stability alternating with sudden changes or critical transitions of the socio-ecological system [2,7]). These sudden changes are often not foreseen by management practices due to the nature of changes; these approaches are commonly defined by law-enforced threshold levels along environmental gradients [8]. Interventions to inform policy or management are therefore ineffective or not timely enough to maintain ecosystems with multiple socio-ecological functions in a state of prolonged stability.

Thresholds and tipping points are important focal points for adaptive management [9-12], but often lack data to define exact biophysical thresholds to model the complicated interactions in SES models [13]. However, several ecological indicators [14] and policy-based approaches do exist to determine when the limits of a system are reached, and when future change will become critical for the system. Examples include flood mitigation through adapting infrastructure [15-18], adapting water resources management with decision frameworks $[19,20]$, and institutional adaptation, through the inclusion of capacity building by government agencies [21,22]. Despite the considerable body of the literature, there has been limited focus on: (1) defining thresholds for ecosystem processes, (2) how to inform policies that environmental change has become critical [23], and (3) when interventions are needed to address different key ecosystem processes.

A policy-based approach that defines when and which objectives of a current strategy are being met, is a starting point to adapt existing strategies and formulate new ones, is referred to as the Adaptation Tipping Point (ATP) method [16]. An adaptation tipping point is the moment when the magnitude of change is such that a current management strategy can no longer meet its objectives. As a result, adaptive management is needed to prevent or postpone these ATPs. This method has previously been applied to river restoration and a species re-introduction programme [24-26]; unfortunately, the approach fails to address whether or not current management strategies are sustainable when system behaviour is poorly understood, and when there are time lags that are involved for different subsystems in a larger SES [11]. However, the ATP approach confronts the lack of quantitative and qualitative ecological data sets to infer acceptability of management $[10,27,28]$ by using stakeholder engagement to determine unknown/ill-defined thresholds, and thereby prevents a focus on only existing management strategies [26,27]. To prevent confusion with definitions of tipping points in other fields (e.g., climate sciences, ecology), we will use the term "adaptation tipping point" in this study.

A management strategy needs to be informed about when an ecosystem could shift into an alternate state that will have low resilience when the system is exposed to stressors induced by climate change. Wetlands are ecosystems that are particularly vulnerable to decreased ecological resilience due to factors such as, altered hydrology, invasive species, nutrient loading, and fire regimes, that can cause wetlands to shift from a "clear-water" to "turbid-water" stable state, or from a permanent to a seasonal hydro-regime that inadequately supports ecological processes [2,3]. In light of current management strategies and shortcomings, we are interested in how much hydrological variation an ecosystem can cope with before the durability of a strategy to conserve the ecosystem expires, and when this will occur. The overall aim of this study is to provide a modified ATP framework to identify the effectiveness of ecosystem management strategies; this will be applied by using a case study. The effectiveness of the ecosystem management strategy is defined using three ecosystem functions: 
1. hydrological response and variation;

2. temporal scale ecosystem responses; and,

3. recovery rate or alternative stable state of ecological processes.

\section{Method}

The original five-step ATP methodology includes (Figure 1): (i) the determination of climate change effects on the system; (ii) followed by identifying key objectives and thresholds; (iii) the determination when standards were compromised in the past; (iv) analysing when standards were compromised in the future; and, (v) to repeat step 1-4 for alternative strategies. Further details about the original methodology can be found in [16]. We modified the original methodology to determine ATPs for different socio-ecological objectives and thresholds with the assessment of historical hydrological time series. We expanded step 3 to interpreted ATPs in conjunction with the hydrological response and variation; temporal scale ecosystem responses; and, recovery rate and alternative stable state of ecological processes (Figure 1).

\section{ATP Assessment}

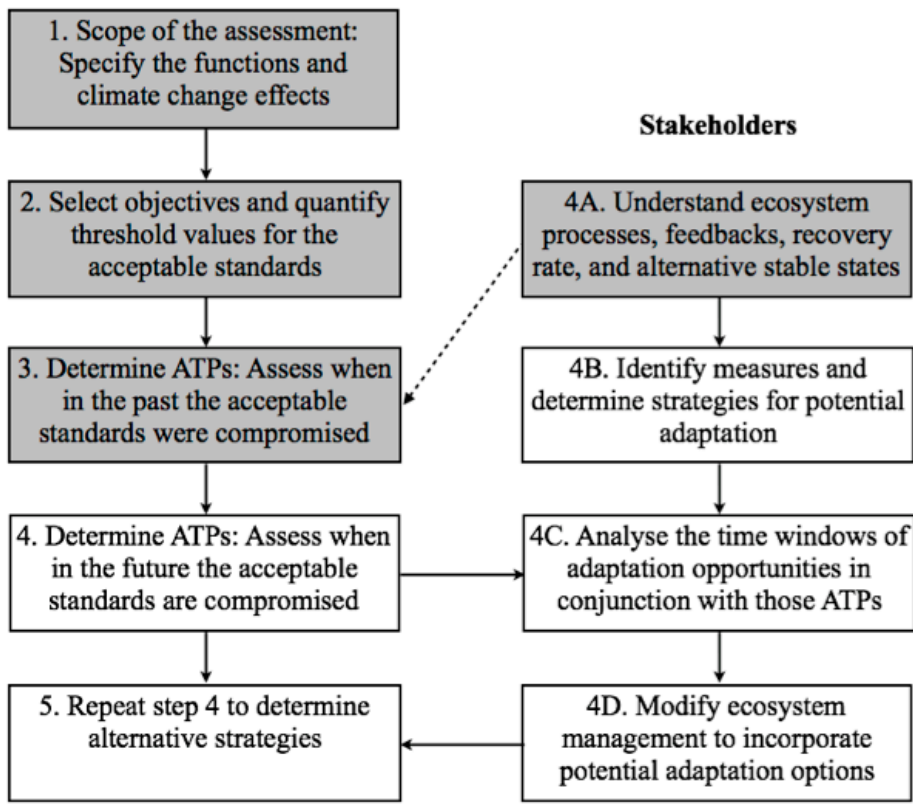

\section{Data collection and analyses}

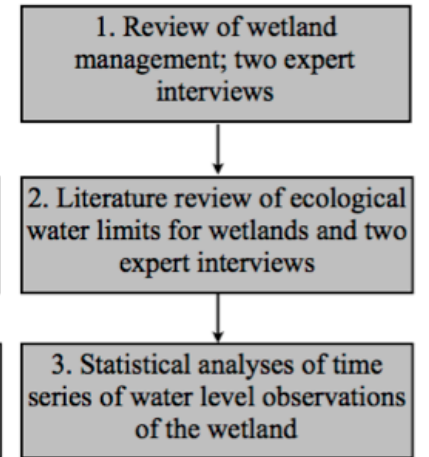

Figure 1. The complete Adaptation Tipping Point (ATP) methodology with an overview of the steps undertaken in this study (indicated with grey boxes), along with the data collection and analyses conducted in this study (Adapted from: [16]).

\subsection{Case Study Area}

The wetland in our case study area, Forrestdale Lake (Figure 2), is located in the biodiverse region in south-west Western Australia [29], and has been noticeably impacted by anthropogenic factors $[30,31]$. The wetland supports many waterbirds and its surrounding riparian vegetation supports terrestrial birds, significant reptiles, mammals, and other vertebrate species [32]. The lakes' high biodiversity makes it an important regional conservation area [33]. An estimated 85\% of the Swan Coastal Plain (SCP) wetlands have been lost since colonial settlement and are likely to experience increasing hydrological stress due to further decreasing rainfall $[32,34,35]$ and catchment urbanisation [36]. The wetland experiences a Mediterranean climate with a mean annual rainfall of 852 $\mathrm{mm}$ in the period 1980-2014. Approximately $80 \%$ of the annual precipitation occurs in winter between May and September, with groundwater recharge occurring from June to September [37]. 


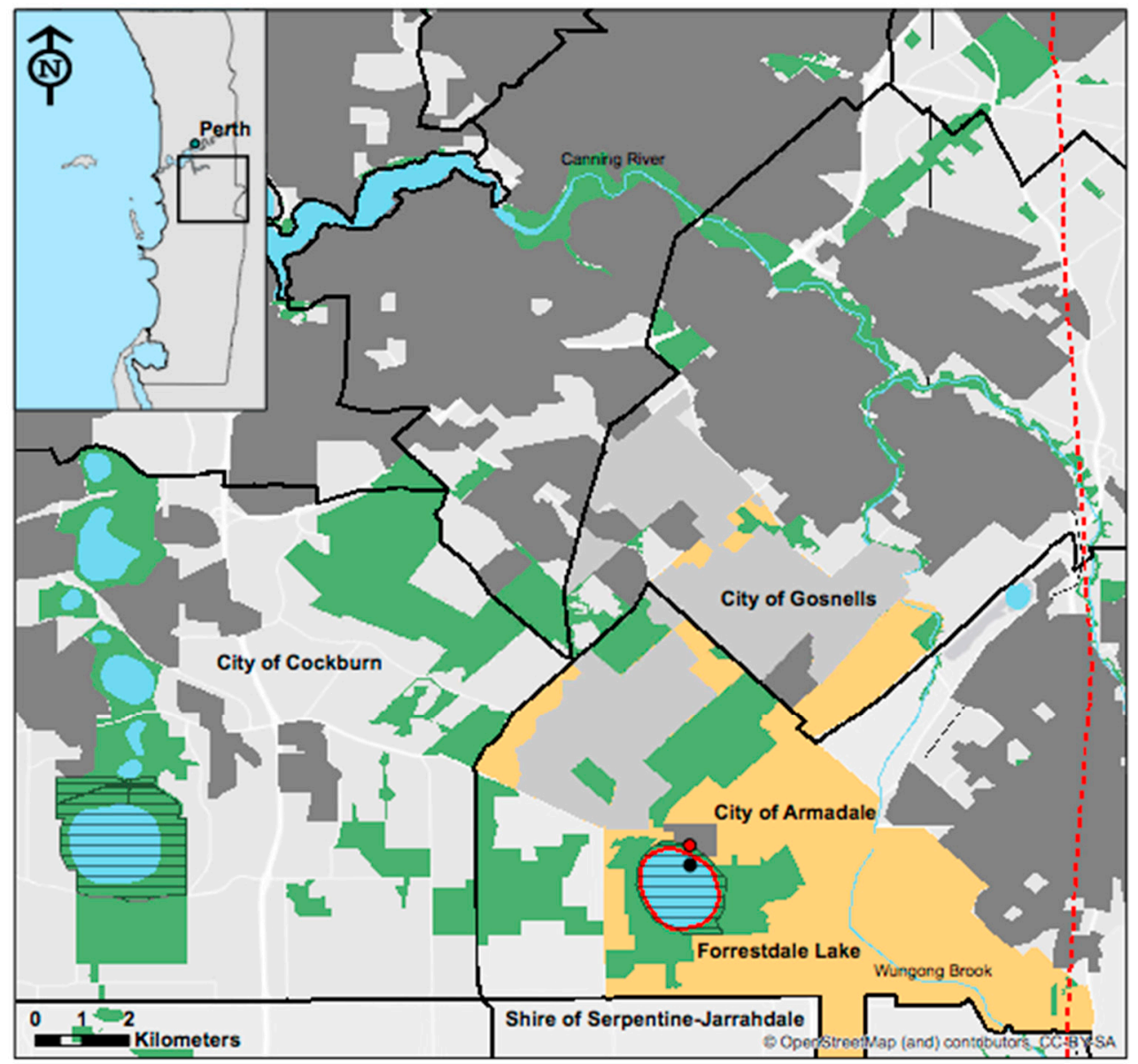

(a)

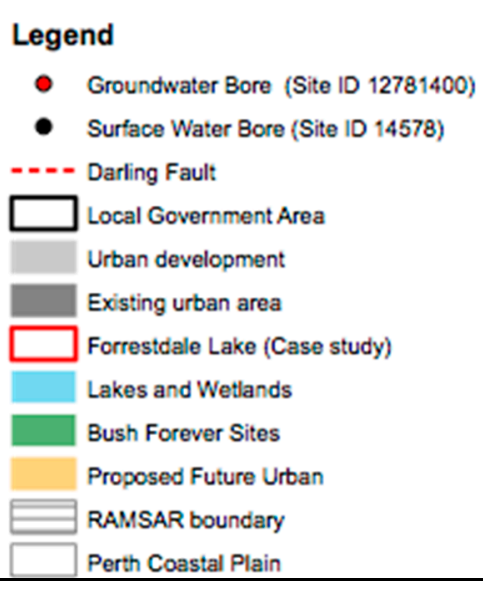

(b)

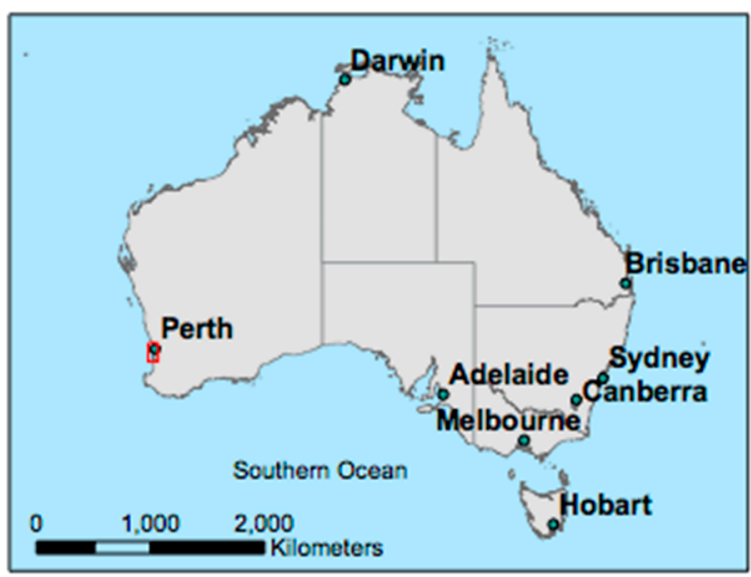

(c)

Figure 2. Location of Forrestdale Lake $\left(32^{\circ} 09^{\prime} 30^{\prime \prime} \mathrm{S}, 115^{\circ} 56^{\prime} 16^{\prime \prime} \mathrm{E}\right)$ within its groundwater catchment, showing the increasing urbanisation in the catchment, the multiple management authorities, and protection policies (Map projection: GDA94). (a) Catchment characteristics of Forrestdale Lake; (b) Legend; (c) Location of Forrestdale Lake.

Climate change, via its impact on rainfall and groundwater recharge, is an important regional driver of wetland hydrology and ecological functions [38,39]. Since the 1970s, this region has experienced a $10-20 \%$ decrease in average annual rainfall that resulted in a mean annual rainfall of $775 \mathrm{~mm}$ in the period 2004-2014 [40-42]. There is evidence that climate change has been impacting 
the hydrology of the unconfined aquifer since the 1970s [43-45], leading to less surface water availability [46,47]. Local-scale hydrologic changes associated with land-use change and groundwater abstraction may also impact water levels of wetlands. Although, these changes are considered minimal when compared to region-wide changes in rainfall and consequently recharge of the aquifer $[48,49]$. A growing population and greater demand for groundwater (Figure 3) is expected to put more stress on the already over-allocated groundwater resources.

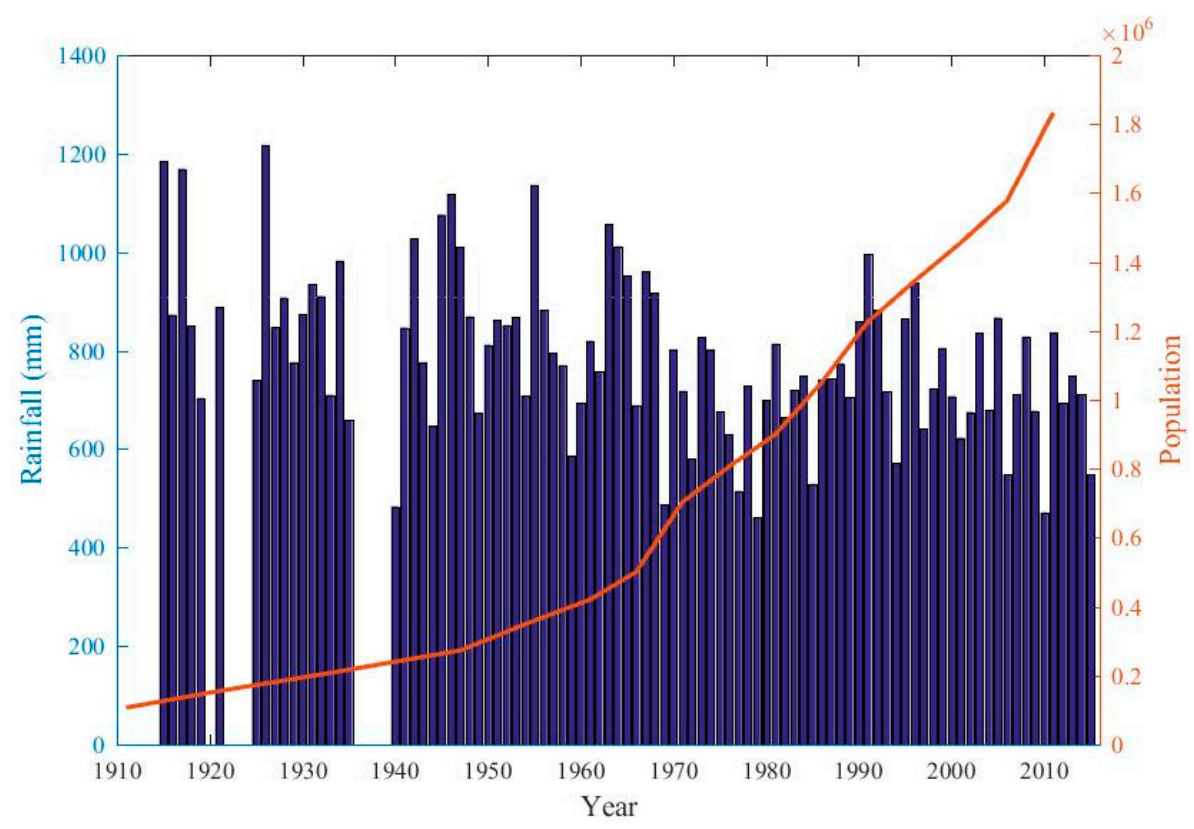

Figure 3. Population growth in Perth between 1910 and 2015 [50] shown against the annual rainfall data over the same period, where available [51]. The decreasing annual rainfall results in reduced water availability.

When considering that the case study area is under multiple stressors, it is expected that current management policies are already inadequate, and that management authorities have the desire to understand past effects of climate change on maintaining individual socio-ecological objectives. With the high likelihood of a management plan that needs to be updated according to new research findings, multi-scale policies requiring review, and limited availability of ecological and hydrological data, the ATP methodology is suitable to apply to this wetland.

\subsection{Data Collection and Analyses}

Data were collected, and thresholds defined through a literature review and interviews. Hydrological time series data for each socio-ecological objective from the management strategy [52,53], and minimum and maximum water level thresholds were compared with mandated management objectives and policies, respectively [54].

\subsubsection{Step 1: Legislative Framework and Impacts of Climate Change-Literature Review}

The legislative framework consists of gradually introduced laws and policies first aimed to protect the rights to use groundwater resources, and more recently, to protect the natural resources. In Figure 4, we present a timeline of the legislation framework for Forrestdale Lake and its groundwater catchment area, with key social and environmental events that have occurred. During the time period from colonial settlement until the mid-20th century the wetlands suffered due to negative perceptions of mosquitos, and through degradation due to land use changes. As the degradation of the environmental resources progressed, new knowledge about the ecosystem helped to shift legislation to protect species 
and ecosystems. Prior to the 1950s, the wetland was classified as a 'groundwater through flow lake', but is now, depending on rainfall and groundwater, considered a 'permanently inundated and perched lake' [55-57]. However, even more recently a combination of disconnection from groundwater and decreasing annual rainfall has resulted in the lake only being seasonally inundated (CCWA 2005); the trend of the drying climate is likely to continue during the 21st century $[40,42]$. We reviewed all of the policies and legislation that have been introduced to protect the wetlands, including policies that are aimed to protect groundwater resources, species, and connectivity of green zones within urban areas. Legislation and policies have been introduced on both state and national levels; on the local level, statutory documents are produced that provide detailed environmental objectives and an overview of the responsible managing authorities.

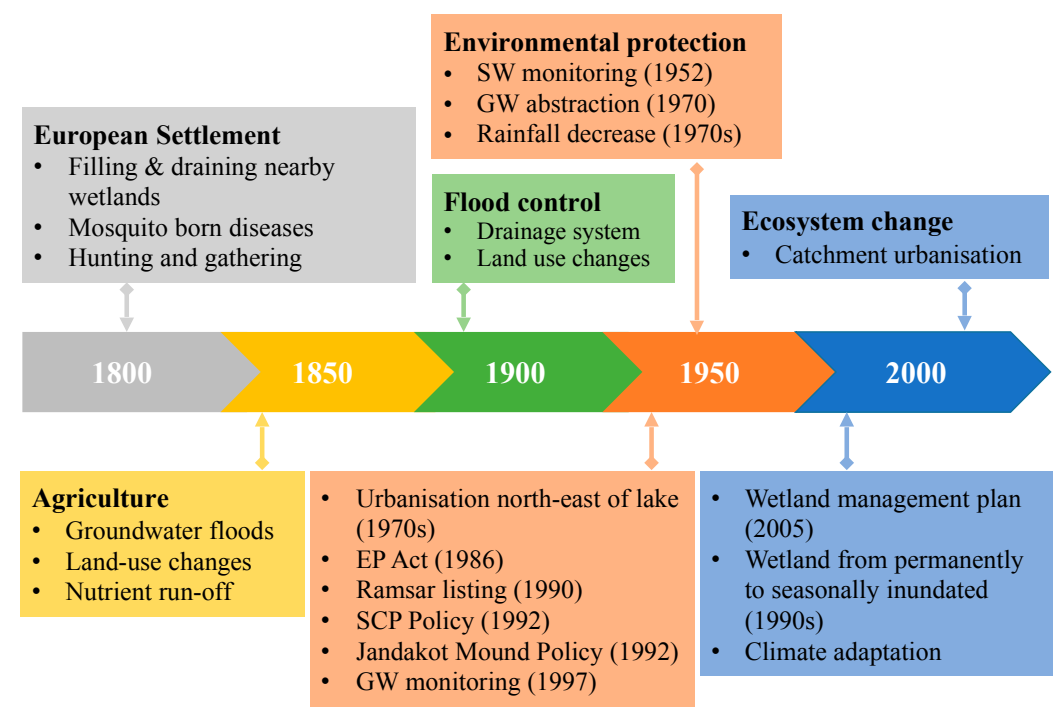

Figure 4. A historical representation of time and scale the traditional human-nature system and water resources system of Forrestdale Lake with indicated key events of the four subsystems: Natural resources, infrastructure, socio-economics and institution.

\subsubsection{Step 2: Select Objectives and Quantify Threshold Values-Literature Review}

In the second step, we reviewed the current wetland management strategy for policy objectives, indicators, and threshold values of the wetland ecological processes. These functions represent the critical objectives of the wetland management strategy. Certain water depths are needed within a wetland to sustain a variety of ecological processes $[36,38,58,59]$, therefore we used water depth as a proxy to link ecological objectives to mandated policy thresholds [54], shown in Table 1. We identified two pathways within the SES via which water depth may impact on wetland ecological objectives:

i Water depth may reach levels that are too low to:

- maintain sediment processes;

- provide habitat needed by waterbirds, frogs, freshwater turtles, and macro-invertebrates for survival and reproduction;

- $\quad$ inhibit the growth of mosquitoes and midges.

ii Water depth may reach levels that are too low or too high, such that they lead to:

- the death of phreatophytic (i.e., groundwater dependent) and fringing vegetation;

- the compromise of the habitat needed for terrestrial birds and mammals; and,

- increased weed invasion and compromise the habitat needed for wading birds. 
Table 1. Threshold values for the ecological objectives to determine ATPs for surface water (SW) and groundwater (GW) levels in (non)-consecutive months derived from the state water policy. $21.6 \mathrm{~m}$ AHD (mean water level in Australian Height Datum in meters) is the height of the lake bed, which we here denote as zero; all thresholds are defined as water depth with respect to the lake bed.

\begin{tabular}{lccc}
\hline \multicolumn{1}{c}{ Ecological Objectives } & Water Level $\mathbf{( m )}$ & Threshold Definition & Source \\
\hline 1. protect vegetation and mammals; & $\mathrm{SW}<0$ & 3 consecutive months; 1 in 5 years & {$[33,54,58]$} \\
definition of drought & $\mathrm{SW}<0$ & 1 month per year; 1 in 1 year & {$[33]$} \\
2. prevent mosquitoes & $\mathrm{SW}<0$ & 6 consecutive months; 1 in 5 years & {$[33,54,60]$} \\
3. protect waterbirds & $\mathrm{SW}<0$ & 8 months; 1 in 5 years & {$[58,59]$} \\
4. protect frogs & $\mathrm{SW}<0$ & 3 months; 1 in 5 years & {$[58,59]$} \\
5. protect tortoises & $\mathrm{SW}<0.4$ & 3 consecutive months; 1 in 5 years & {$[58,59]$} \\
6. protect macro-invertebrates & $\mathrm{GW}<-0.5$ & 3 consecutive months; 1 in 5 years & {$[58]$} \\
7. prevent exposure of Acid Sulphate Soils & $\mathrm{GW}<-0.5$ & 3 consecutive months; 1 in 5 years & {$[58]$} \\
8. maintain sediment processes & &
\end{tabular}

From the aforementioned pathways, we derived eight critical ecological objectives, as shown in Table 1. The objectives were taken from the Forrestdale Lake wetland management strategy [33]; the Ministerial Water Requirements [54], and from discussion with two experts from different management authorities (the Department of Parks and Wildlife and the Department of Water; since 2017 the Department of Biodiversity, Conservation and Attractions and the Department of Water and Environmental Regulation resp.). For each ecological objective, minimum water depth requirements were obtained (i.e., threshold) using the Ministerial water requirements (Table 1). $21.6 \mathrm{~m}$ AHD is the height of the lake bed, which we here denote as zero; all of the thresholds are defined as water depth with respect to the lake bed. The appraisal of the ecological objectives in Table 1 reveals an inundated lake is needed to support the socio-ecological objectives. The minimum water level (depth) for vegetation, mammals, and terrestrial birds is $>0 \mathrm{~m}$.; and $0.4 \mathrm{~m}$. to maintain waterbirds, freshwater turtles, frogs, and macro-invertebrates (Table 1). In cases where water level thresholds were not informed by the Ministerial water requirements, we relied on peer-reviewed literature (See 'Source' column, Table 1). A detailed description of each ecological objective were obtained from previous research [32,48,52,60-62]. In addition, two expert interviews were conducted to determine both the accepted exceedance frequency, and to define threshold definitions not previously included in policy or the literature. We also included experts from other government department and actors that are involved in the management of the wetland to discuss the threshold definitions and determine the consensus for using these threshold values. These actors are listed below with their role and tasks:

- the local government (city council, responsible for land division and drainage);

- the State Department of Parks and Wildlife (conservation authority);

- the Department of Water (water regulator, responsible for ground- and surface water allocation and monitoring); and,

- community and local conservation groups (community, involved in monitoring birds, revegetation and rehabilitation of the wetland buffer zone).

\subsubsection{Step 3: Determine ATPs—Statistical Analyses}

Time series datasets of surface and groundwater depths [63] were sourced from the Department of Water's water information database. The data were divided into two time periods, 1978-1995 and 1996-2012, so that each period reflects a sufficient amount of time for policy implementation and linked to the downward trend in rainfall. To evaluate the ecological resilience of the wetland, we assessed when and for how long the water level in Forrestdale Lake crossed the thresholds. In order to estimate the frequencies of occurrence of threshold exceedance (see thresholds, Table 1) by annual minimum series, we used the observed historical time series of water levels and the following equation proposed by [64]: 


$$
G(x)=1-\left[1-k\left(\frac{x-x_{0}}{\alpha}\right)\right]^{\frac{1}{k}} \text { for } k \neq 0
$$

where $G(x)$ is the distribution of the magnitude of events $(x)$ smaller than a threshold $\left(x_{0}\right)$ over a (non)-consecutive duration over a period of years $(T)$. Here, $\alpha$ and $k$ are constants derived from the average highest and lowest values in sets of $T$ annual minima, and the minimum value to be expected once in $T$ years. Arrival rate $(\lambda)=$ the average number of minimum values $\left(x_{0}\right)$ per year. Constant $\alpha=(2 \times 10.88)-\lambda 1=-0.05$; Lower bound $(\xi)=\lambda-(0.5572-\alpha) \times 0.5572=$ constant; Probability value $(\mathrm{p})=(1-(1 / \mathrm{T})$; Expected water levels $=\xi-(\alpha \times \mathrm{LN}(-1 \times \mathrm{LN}(\mathrm{p})))$.

To interpret the occurrence of ATPs in context with the ecological tipping points; we extended our analyses by comparing the drought frequency, duration, and start month for both the pre- and post-1995 water-level time series. A drought was defined by experts as a dry period when the water depth was zero $\mathrm{m}$. for three consecutive months. We compared the water levels with the available historical ecological data to make an estimation of the trajectories over time.

\section{Results}

The results are presented in accordance with our methodology, as per Figure 1 (Column ATP assessment). The results of the literature review (Step 1), along with an analysis of the multi-scale legislative framework of the case study area (Step 2) are presented in Section 3.1, while the results from the time series analyses (Step 3) of historical surface and groundwater level data from 1978-2012 are presenting in Section 3.2. The understanding of alternate systems states with the ATP assessment (Step 4A) is presented in Section 3.3.

\subsection{Legislative Framework across Scales}

The scope of the assessment for Forrestdale Lake was defined as stipulated in existing legislation (Supplementary Materials). In Western Australia, the Environmental Protection Act (1986) [65] is the legislative act that underpins the environmental protection of wetlands. According to the Environmental Protection Act, the Ministerial water requirements for the Gnangara Mound and Jandakot wetlands (1992) [54] mandates ecological water requirements that consist of upper and lower thresholds to maintain ecological processes; the State water regulator holds the responsibility to maintain these water requirements. Protection of biodiversity or conservation values, such as maintaining biodiversity, is included in the Conservation and Land Management Act (1984) and the Wildife Conservation Act (1950) [66,67]. Large regional wetlands have also been listed under the Ramsar Convention (e.g., Forrestdale Lake) to protect waterbirds (Ramsar 1994) [68], as well as to protect migratory birds under several international agreements (JAMBA 1981; CAMBA 1988; ROKAMBA 2006) [69-71]. However, the protection of nationally and internationally important flora, fauna, and ecological communities is arranged by the Commonwealth of Australia under the Environment Protection and Biodiversity Conservation Act (EPBC 1999) [72]. The above-mentioned Acts and Agreements provide the statutory base to formulate wetland management plans. In contrast to international conventions and Commonwealth legislation, the State government departments and local governments cooperate to maintain the ecological functions, as described in the wetland management plan. A previous wetland management plan from 1993 for Forrestdale Lake was updated in 2005; this now includes the ecological values of the wetland, proposes management actions to control invasive species, and mentions the risks of declining water levels [33]. However, the plan fails to address how to cope with declining water levels.

The literature review revealed that the protection of the regionally important Forrestdale Lake wetland is provided by legislation and policies on different levels and scales (Figure 5). The management of the lake is therefore organised on different levels of government departments that have their own scale of operation (e.g., local council vs. state-wide department). Due to the different institutions and their operational levels, the execution of the wetland management strategy is a 
shared responsibility of all of the stakeholders. However, the co-ordination of this strategy is the responsibility of a government department with state-wide legislative powers (Department of Parks and Wildlife). System controls (e.g., policy and legislation) are mandated on larger spatial scales, whereas accumulated stressors (e.g., reduced rainfall or lowering groundwater table) have larger impacts on lower spatial scales, such as on the whole ecosystem scale or only on part of it. Drying of the lake and ecological degradation are translated by threshold exceedance of ecological processes. Also, the separation/disconnect of water and ecological policy increases the risk of mismanagement. For example, the Department of Water is responsible for groundwater abstraction and the reporting of threshold exceedance to the environmental regulator (the Environmental Protection Authority). While the State government needs to ensure that the ecological functions of the lake are maintained, the Department of Parks and Wildlife is responsible for the ecological state and not for water related management.

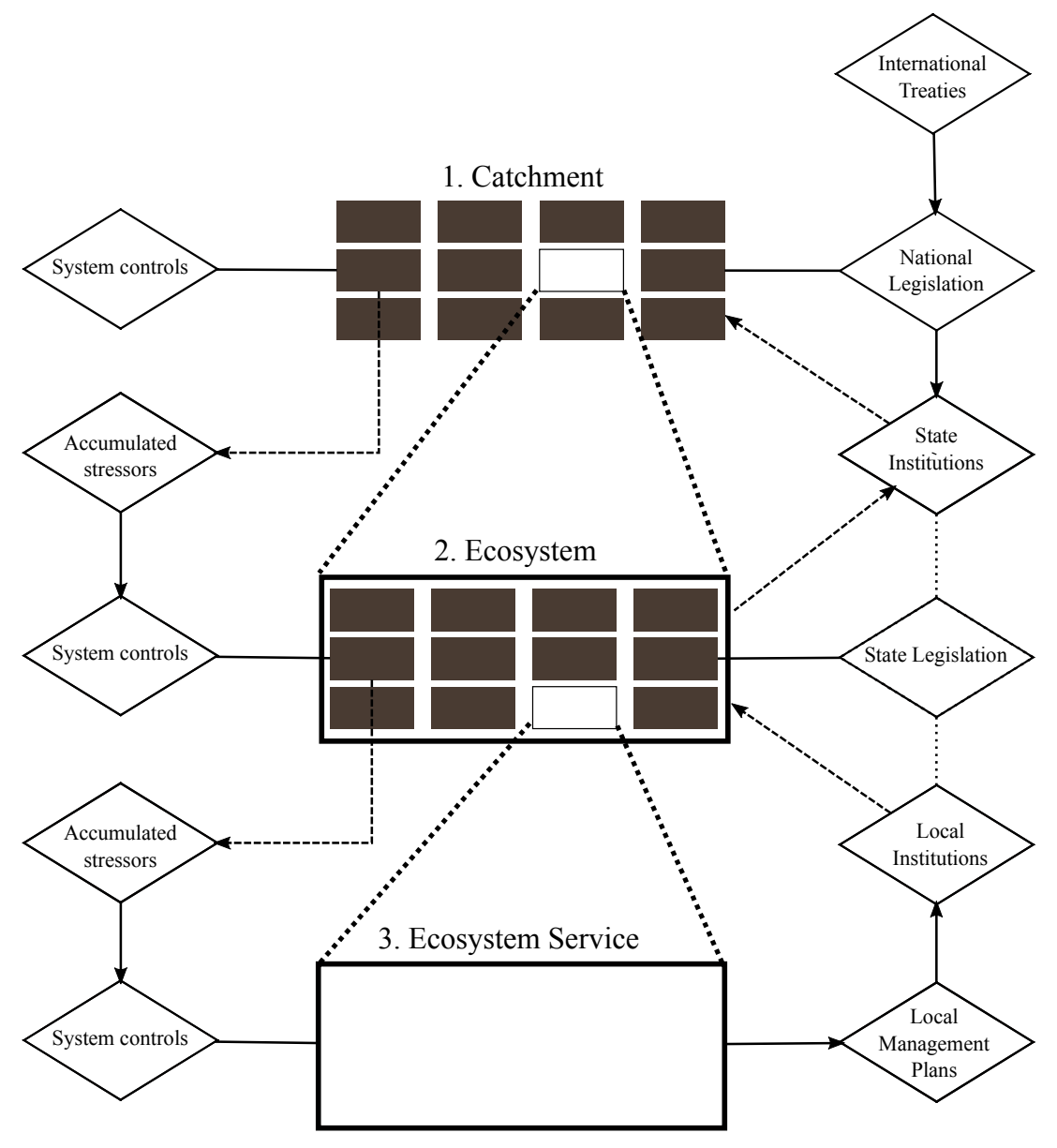

Figure 5. Ecosystem and legislative organisation: across spatial levels of ecosystem organisation stressors are accumulated and trigger a response for system controls in the legislative organisation. Due to fragmented legislative organisation responses are inadequate to maintain ecological resilience.

From the extensive variety of policies and legislation in place to protect the ecological values of the wetland, we were able to derive the important socio-ecological objectives for the wetland. For each objective, we determined the critical water requirement thresholds. However, the water requirement policies did not provide maximum exceedance frequencies (return period) for each objective in our analyses. Where return periods for certain objectives in the management strategy were lacking, stakeholders were able to provide expert knowledge to determine threshold definitions, such as for drought duration, water availability for birds, and exposure of acid sulphate soils. 
The findings from the interviews with experts showed that the legislation and policy aims are a good starting point for discussion with stakeholders that operate on a state-wide scale. The experts interviewed represent management authorities that are responsible for the implementation of larger scale (top-down) policies and legislation, and their roles are to build consensus with other governing institutions that contribute to the wetland management plan.

A combination of a review of peer-reviewed literature and government reports provided a comprehensive overview of ecological studies that were undertaken in Forrestdale Lake. Data are predominantly available in government reports rather than in peer-reviewed media. This included data on bird counts, macro-invertebrate species composition, and vegetation transects. Ecological data is often patchy and only available for certain time frames in the 1990s and 2000s for Forrestdale Lake. Bird counts for the lake have been discontinued since 2009 [73] and vegetation transects are not conducted on regular basis as mandated in policy. Groundwater level data was only available from 1997, while surface water levels were recorded from 1952. In addition, surface water level observations from 1952-1978 contained too many data gaps to adequately perform ATP analyses, as consecutive observations up to six months are not available.

\subsection{ATPs and Ecological Resilience}

ATPs were determined by calculating the re-occurring water level depth using the values from Table 1 with Equation 1. The time series analysis employed here suggests that a drying climate has compromised four ecological objectives of Forrestdale Lake (Table 2). ATPs occurred after 1995 and threshold crossings occurred for vegetation and mammals, waterbirds, turtles, and macro-invertebrates. Water levels for the remaining objectives are close to exceeding thresholds, such as the capacity of the lake to deliver sediment processes and limiting the risk of oxidation of acid sulphate soils in the lake bed.

Table 2. Adaptation tipping points calculated with eq. 1 for each ecological function of Forrestdale Lake. Bold values indicate that the water level is below the threshold value and consequently result in an ATP. The two time periods reflect the timeframe for policy adaption. SW = surface water; GW = groundwater.

\begin{tabular}{lccc}
\hline \multirow{2}{*}{ Ecological Objective } & \multicolumn{3}{c}{ Water Level (m) } \\
\cline { 2 - 4 } & Threshold & $\mathbf{1 9 7 8 - 1 9 9 5}$ & $\mathbf{1 9 9 6 - 2 0 1 2}$ \\
\hline 1. protect vegetation and mammals & $\mathrm{SW}<0$ & 0.06 & $\mathbf{- 0 . 2 1}$ \\
2. prevent mosquitoes & $\mathrm{SW}>0$ & -0.27 & -0.19 \\
3. protect waterbirds & $\mathrm{SW}<0$ & 0.24 & $\mathbf{- 0 . 1 6}$ \\
4. protect frogs & $\mathrm{SW}<0$ & 0.42 & 0.01 \\
5. protect tortoises & $\mathrm{SW}<0$ & 0.06 & $\mathbf{- 0 . 2 1}$ \\
6. protect macro-invertebrates & $\mathrm{SW}<0.4$ & 0.06 & $\mathbf{- 0 . 2 1}$ \\
7. prevent exposure of Acid Sulphate Soils & $\mathrm{GW}<-0.5$ & 0.06 & -0.21 \\
8. maintain sediment processes & $\mathrm{GW}<-0.5$ & 0.06 & -0.21 \\
\hline
\end{tabular}

Figure 6 shows that Forrestdale Lake dried more frequently than the recommended return period of one in five years, and that each dry period exceeded the maximum duration of three consecutive months. Drying is most frequent in summer (December, January, and February) which is in line with regulation that drying of the lake should not occur before April/May, in order to ensure a waterlogged lake bed throughout the year. When the drought frequency and duration are compared for both periods, pre-, and post-1995, no droughts according to the policy definition occur. However, the lake did dry completely for shorter durations during summer. In contrast to the regulation, it is completely logical that drying is more likely to occur over summer, with longer periods per year of limited water availability for species. 


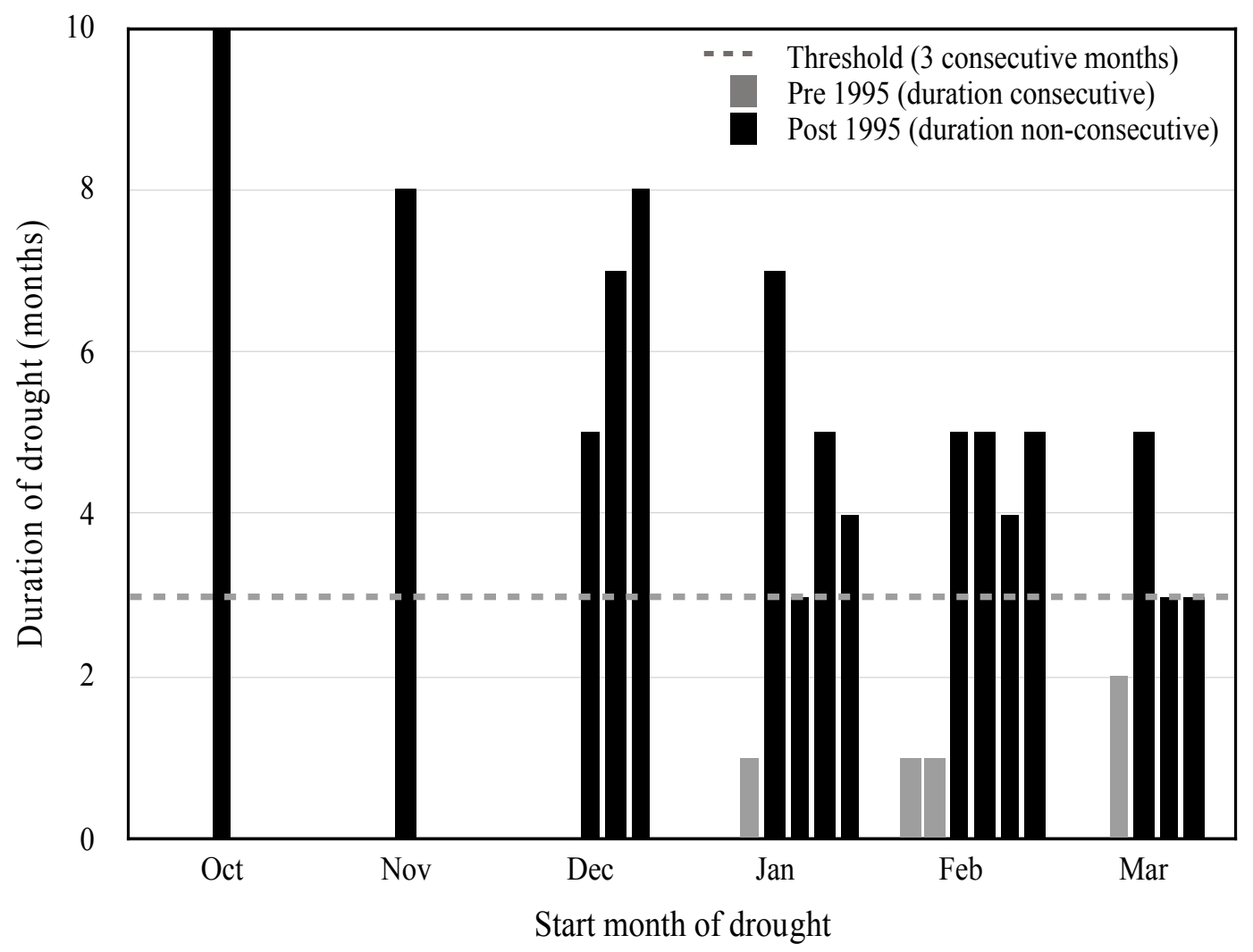

Figure 6. Comparison of the onset and duration of drought during the period 1978-2012 at Forrestdale Lake, shown pre and post 1995 . The policy definition of a dry period is $\geq 3$ consecutive dry months which must not start prior to April/May. Each bar represents a dry period and respective start month. Drying of the lake prior to 1995 is added as a reference, as the lake dried in the period, but, according to the policy definition, was not considered as drought.

Although there was not enough data to conduct trend analyses, the frequency of droughts and the duration of each drought has markedly increased since 1995. When we combine the results from our ATP analyses (Table 2) with the drought analyses (Figure 6), we observe a regime shift in the ecosystem from a permanently to seasonally inundated wetland. The effect of this hydrological shift translates into failing to meet the defined threshold level that is enforced in policy and leading to an ATP. In Figure 7 we graphically present the minimum thresholds for all of the objectives, the water levels from 1978-2012 as compared to the initiation of groundwater abstraction, and the implementation of the water policy requirements.

Frequent water level and drought exceedance for objectives only occur in the period after the water policy was implemented in 1992. Between the 1970s and the implementation period of the water policy in 1992, no significant research was conducted on the gradual decline of water levels in the Swan Coastal Plain wetlands. With available quantitative ecological data on ecological responses we base our representation on stylised lines to explain individual ecological responses when compared to declining water levels from the 1970s (Figure 7). This representation is a combination of historical data from previous research and information from the expert interviews (Supplementary Materials). The decline of the ecological processes coincides with the increased duration and frequency of dry periods during the 1990s. After the mid-1990s, we observe that the management of the lake did not respond to maintain declining water levels on the mandated threshold levels; indeed, the minimum water requirements for the wetland were not updated during the period 1992-2005. However, new water level requirements were proposed in 2005 to reflect the current hydrological regime of the wetland. 


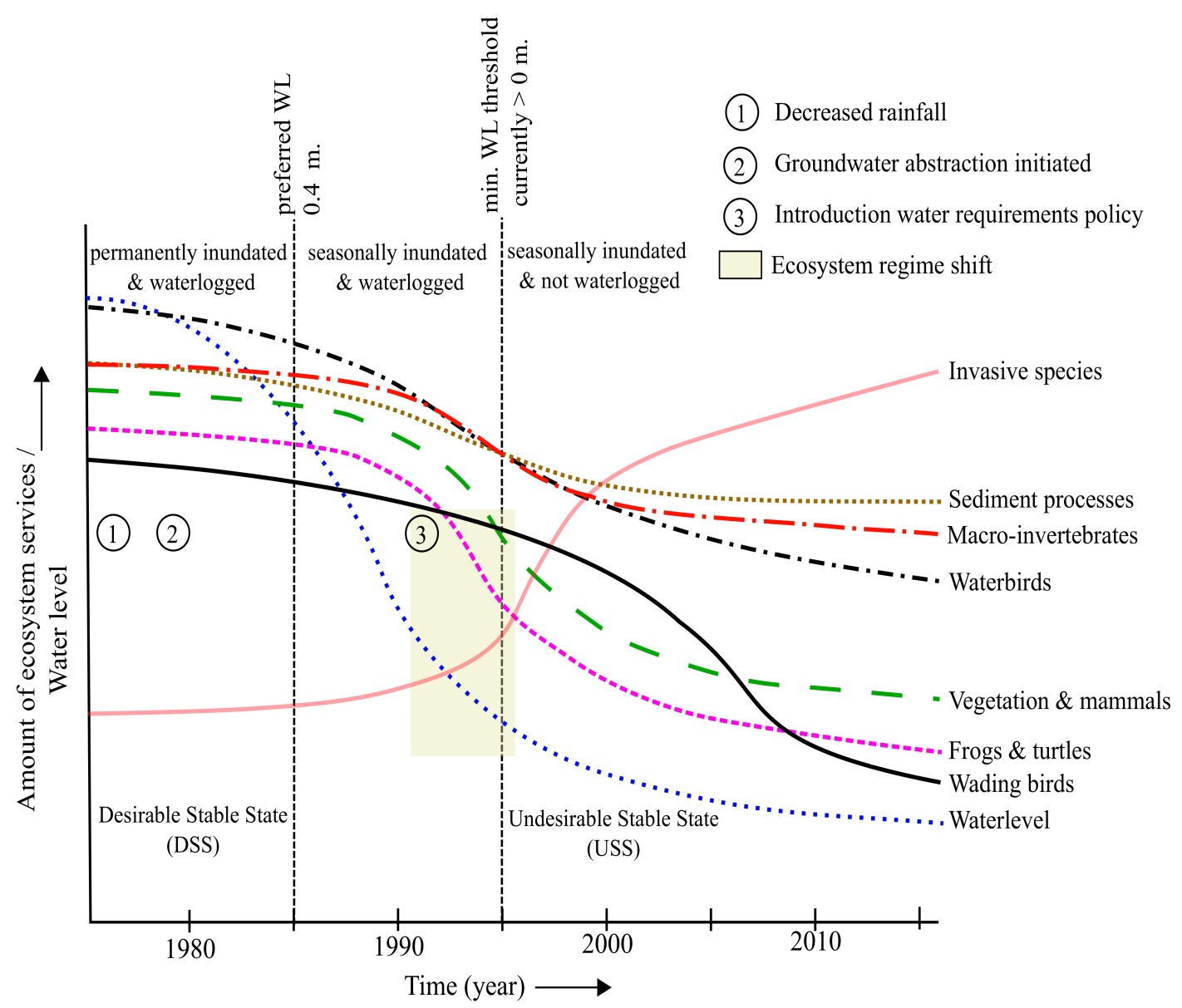

Figure 7. Ecosystem regime shift on the onset of dry periods with declining water levels (WL) and the change of conditions of ecological processes over time. Incremental management and policy compared to non-linear ecosystem responses over time are ineffective when sudden changes occur.

\subsection{ATP Assessment and Alternate System States}

A major gap in the science-policy interface and socio-hydrologic systems literature is here defined as: (i) the identification of inadequate policy to inform managers or policy makers about the durability of an ecosystem management strategy; or, (ii) the performance of assessments of hydrological variables when data is lacking. With the ATP methodology presented, where possible, we have tried to close the gaps in the literature. The methodology presented assessed whether an existing baseline ecosystem management strategy was sufficient to sustain the ecological resilience of the ecosystem. With the ATP framework, we assessed resilience of the hydrological system across spatial and temporal scales by the: (i) magnitude of the reaction of the ecosystem; (ii) temporal scale and ecosystem responses to increased perturbations; and, (iii) recovery rate or shift from a desirable stable state to an alternate/undesirable stable state with limited ecological processes [74]. We linked eight critical socio-ecological objectives to explain subsystem changes and the implications for decision-making to reach mandated policy thresholds, which was considered a literature gap for ATP assessments [11].

\section{Discussion}

\subsection{Temporal and Spatial Hydrological Responses in Atp Analysis Applied to Ecosystems}

The observed climatic shift evident in the late 1960s/early 1970s in south-west Western Australia [75] follows the stepwise decreasing rainfall trend in our hydrological time series. With shorter periods of inundation in the 1990s a hydrological response is evident, and ATPs occur 
simultaneously in the same time period. The hydrological shift from permanent to intermittent water availability in the lake due decreased surface water availability from lower rainfall is explained in previous studies $[38,57,76,77]$. The observations of consistent reductions of water levels result in more frequent, prolonged dry periods, and studies confirm that a significant reduction in water levels for consecutive years could threaten the regional function of wetlands to sustain multiple ecological functions [76-78].

The analysis points to an ineffective water requirements policy, as water levels requirements are not met for four of the eight ecological functions; thresholds were crossed in the 1990s, which occurred concurrently with the observed hydrological response. The main ecological processes of the lake depend on waterlogged soils during low water availability, however are at increasing risk when the lake bed dries completely over summer. Early drying of the lake implies a lack of surface water availability for species that have a limited action radius to alternative habitats, such as macrophytes, freshwater tortoises, frogs, and macro-invertebrates. Our study did not include the investigation of ecological responses, however, the hydrological change and ATPs are followed by declining trends in the ecology. Previous studies on this wetland have shown:

- increasing weed invasion and exotic species establishing in the understory, along with deterioration of fringing vegetation [76,78];

- a gradual declining trend in the species numbers and composition of macro-invertebrates; in particular, a reduced number of families was observed (down from 40 in 1987 to 34 in 2009 [61]) due a loss of some species [46,60,77]; and,

- decreasing numbers of birds from over 20.000 birds in the 1980 s to just over 10.000 birds in 2009 [79].

The responses of ecosystems after perturbations, and the shifts that could occur from a desirable higher stable state into an undesirable lower stable state with higher resilience and reduced ecological processes are described in the literature [2,3,12]. However, a lack of data makes it difficult to determine shifts between multiple or alternate stable states [80]. From our results, we see that a gradual transition of the boundary condition (reduced rainfall) failed to trigger management interventions to maintain the rapid responses in an ecosystem. Management responses are also absent when, for example, rapid hydrological processes and the slow response of ecological processes, such as vegetation shifts [81], are not detected when monitored at different spatial scales [82]. This mismatch is magnified when different government departments are responsible for monitoring and management responses.

To draw attention to the different responses of ecological processes we started a discussion among management authorities to consider management objectives and threshold values. The management objectives are derived from different sources such as the State-scale water level criteria; the national (Commonwealth) ecological objectives that are linked to the Ramsar guidelines; and, the key socio-ecological objectives from the local management plan. Currently, Ramsar criteria, such as the number of (water) birds is infrequently monitored, and objectives from the local management plan are only partly monitored (vegetation and macro-invertebrates). The ATP analysis and the discussion among the different actors for wetland management showed that the jurisdiction of the government departments in question does not cover the spatial scale of certain ecological processes. Some ecological processes rely on factors which are managed by different institutions. For example, the decline of vegetation quality depends on regional groundwater availability, which is regulated by the water regulator; whereas, protecting flora in the buffer zones is the responsibility of the conservation authority. Despite the strong indication of declining ecological values, national and state level policies are only partly informed by the policies determined at the local scale. Research confirms the need to incorporate all the relevant institutions to achieve institutional-ecosystem function fit [83], while the identification of underlying gaps in multi-sector governance as described, will form the basis to negotiate closing the gaps in governance. 


\subsection{Informing Ecosystem Management}

The ATPs that are presented in this case study area are intended as guiding principles (early-stage) to existing ineffective ecosystem management strategies. The ineffectiveness of other policies has been shown in: Flood risk studies [15,17], flood mitigation under climate change [18], river restoration [26], and the impact of the hydrological regime of a river on salmon re-introduction, and shipping [24]. Central in these studies is to determine when and how much action is needed to determine alternative management strategies [81], but for a SES, when to take action is far more complicated. Due to the jurisdiction of decision makers or managing authorities, ATPs are used as a starting point to explore if and when adaptation measures need to be taken to adequately resolve the critical adaptation tipping point of different ecological processes [23]. When, such as in our case, quantitative data is not readily available to support a complex model, with predicted feedback mechanism, in the socio-environmental system $[4,5,84,85]$, the outcomes of an ATP analyses provide a better understanding of the role of individual processes before making more complex models [86]; highlighting the potential dynamics of scale of legislation and policy, and the interaction of management authorities in the hydrological system. As described previously, management interventions can be considered by different institutions that will provide the appropriate outcome for each ecological process. This requires understanding the scale and level of policy and legislation in the analysis prior to embarking on a process to deliver adaptation measures for the different socio-ecological objectives, such as those that we included in our analysis.

In order to adequately improve existing management practices, we should first consider the whole set of clearly stated objectives in a management strategy without prioritising or aggregating them. As a result, we may then provide the alternate states of ecological processes within the spatial and temporal scales of processes and governance systems [14]. Introducing multiple management aims overcomes a focus on separate ecological objectives, which may lead to a lack of quantitative boundaries or thresholds for acceptable ecological change $[11,16,28,87]$. Studies have shown that when law or policy enforced threshold levels along an environmental gradient are passed [7], that not all ecological processes will show a direct decline of species or shift in species composition, thus making it more difficult to reverse different conditions of the ecosystem [2]. Therefore, informing decision-makers at an early stage prevents costly measures to reverse undesirable changes to the system.

In the absence of clearly defined thresholds, our framework provides active involvement of the management authorities [10,28] from a multi-purpose perspective [24]. The ATP analyses stimulate stakeholders to look at the resilience of their approach [16]. Continuous improvement in the processes of adaptive management is an ongoing challenge, but studies have demonstrated successful frameworks for collaborative research in the science-policy interface across several scales [88,89]. When management practices need to be updated, the threshold definitions for management approaches should reflect the ideas of multiple management authorities that are involved. In the absence of a combined eco-hydrological and social model, we were able to distinguish the trade-offs between vulnerability (performance) of the ecosystem as compared to thresholds of subsystem processes that were defined by policies and legislation across spatial scales.

\subsection{Adapting Management Strategies}

For effective governance, developing a better understanding of climate and hydrological impacts is required [89]. With the involvement of stakeholders in our assessment, we can account for the exploration of future hydrological events and provide decision-makers the information on under which conditions the current policies will expire; however, the exact timing of expiry remains problematic due to different timescale of system responses. We aimed to overcome this by including threshold values (only partly available) that represent ecosystem processes across scales. Although the ATP assessment includes some options to identify measures for adequate governance decisions; further exploration for how long these are sufficient under future climate scenarios needs to be investigated [10]. This could include: (1) physical/engineered measures, (2) adoption of new or amended policy instruments, 
(3) adoption of policy strategies (combination of options 1 and 2), or (4) implementation of an adaptation strategy $[12,16,90]$. Successful adaptation requires a critical understanding of the scale and level of implementation of existing policies, legislation, or management strategies, as these are often barriers to local scale adaptation.

Despite the exceedance of critical thresholds, management has not adequately responded to changing hydrological variation in the ecosystem. We assumed climate change to be the main external driver for the ecosystem regime shift, although this does not assume a non-adaptive management strategy. The ATP application is adequate for ecosystems when a clear external driver of change can be determined (e.g., climate change), stakeholders agree on setting thresholds, and expand individual management objectives to objectives across several levels of policies. However, the study of systems becomes complicated when multiple stressors are responsible for subsystem change and stakeholders do not include objectives or thresholds defined by different or new policies. The limitations of system study include the effects of multiple stressors on the system, a limited focus on new strategies, and including objectives or thresholds that change over time due to socio-economic changes. In this paper we have addressed the difficulties to determine ATPs for an ecosystem with respect to existing policies and management objectives. Further collection of ecological data and monitoring ecological responses will be helpful to determine alternative strategies with stakeholders to postpone or eliminate existing ATPs, according to the steps of the original ATP methodology. The dynamic adaptive policy pathways approach could be a useful tool to guide this process [10].

\section{Conclusions}

The extended ATP method presented in this paper provides a combination of a qualitative and quantitative analysis of datasets of a wetland ecosystem. We applied the concept of 'adaptation tipping points' to identify when management responses became inadequate to prevent decline in ecological integrity. Through a combination of conceptual and visual representation of the ecological processes, we were able to identify major trends and transitions in the system, in the presence of strong drivers of change and variable hydrological conditions. This approach was useful to determine the effectiveness of an ecosystem management strategy when data availability was limited, and where social-ecological dynamic models to fully assess the tipping point and potential points for interventions were absent. This study showed that a lack of data, quantitative boundaries, or thresholds to define acceptable ecological change can be overcome by the inclusion of pre-existing thresholds based on available information about shifts of the wetland's hydrological regime. This information included the importance of reviewing a range of policies to enable discussion among stakeholders to determine existing and new management objectives/thresholds. Through stakeholder discussions, we found unacceptable adverse ecological changes to the unique set of identifiers, and then used the input of expert knowledge to determine the critical wetland objectives and thresholds for wetland management. We showed that informing stakeholders about the effectiveness of existing wetland policy can be used to adapt or accept objectives and thresholds, both seen here in context with ATPs and undesirable ecological changes. ATPs could be established a proxy indicator for lag-responses in the ecology to adapt ecosystem management in a timely manner before ecological processes deteriorate to unaccepted levels.

Supplementary Materials: The following are available online at http:/ / www.mdpi.com/2073-4441/10/2/234/s1, Table S1. Overview legislation framework; Tables S2-S7. Results from stakeholder workshop 1 with the problem statement, objectives, drivers and performance metrics; Table S8. Identified adaptation measures.

Acknowledgments: This research was funded within program B4.2 of the Cooperative Research Centre of Water Sensitive Cities. The authors thank the Department of Parks and Wildlife and the Department of Water for providing the ecological and water level data of Forrestdale Lake. The RStatistics code to compute the water level data was provided by Chrianna Bharat at The University of Western Australia. Liah Coggins provided valuable feedback to improve the structure of the manuscript. Amar Nanda was supported by a Scholarship for International Research Fees (SIRF) funded by The University of Western Australia. We sincerely thank the stakeholder representatives from each of the government departments that participated in the workshop; all 
subjects gave their informed consent for inclusion before they participated in the study. The research involving human data reported in this study was assessed and approved by The University of Western Australia Human Research Ethics Committee (Approval \#: RA/4/1/7999).

Author Contributions: A.N. designed the study, applied for human ethics approval, collected the data, organised the stakeholder workshop and wrote the manuscript under the supervision of B.G., M.R.H. and A.G.; B.G. assisted with the statistical analyses and provided guidance for the stakeholder workshop; L.B. provided feedback on the ecological analyses and introduction; L.L. assisted with understanding the local and regional hydrology of the lake.

Conflicts of Interest: The authors declare no conflict of interest. The funding sponsors had no role in the design of the study; in the collection, analyses, or interpretation of data; in the writing of the manuscript, and in the decision to publish the results.

\section{References}

1. Holling, C.S. Resilience and stability of ecological systems. Annu. Rev. Ecol. Syst. 1973, 4, 1-23. [CrossRef]

2. Scheffer, M.; Carpenter, S.; Foley, J.A.; Folke, C.; Walker, B. Catastrophic shifts in ecosystems. Nature 2001, 413, 591-596. [CrossRef] [PubMed]

3. Folke, C.; Carpenter, S.; Walker, B.; Scheffer, M.; Elmqvist, T.; Gunderson, L.; Holling, C.S. Regime shifts, resilience, and biodiversity in ecosystem management. Annu. Rev. Ecol. Evol. Syst. 2004, 557-581. [CrossRef]

4. Sivapalan, M.; Savenije, H.H.G.; Blöschl, G. Socio-hydrology: A new science of people and water. Hydrol. Process. 2012, 26, 1270-1276. [CrossRef]

5. Elshafei, Y.; Sivapalan, M.; Tonts, M.; Hipsey, M.R. A prototype framework for models of socio-hydrology: Identification of key feedback loops and parameterisation approach. Hydrol. Earth Syst. Sci. 2014, 18, 2141-2166. [CrossRef]

6. Dudgeon, D.; Arthington, A.H.; Gessner, M.O.; Kawabata, Z.-I.; Knowler, D.J.; Lévêque, C.; Naiman, R.J.; Prieur-Richard, A.-H.; Soto, D.; Stiassny, M.L. Freshwater biodiversity: Importance, threats, status and conservation challenges. Biol. Rev. 2006, 81, 163-182. [CrossRef] [PubMed]

7. Walker, B.; Meyers, J.A. Thresholds in ecological and social-ecological systems: A developing database. Ecol. Soc. 2004, 9, 3. [CrossRef]

8. Walker, B.; Holling, C.S.; Carpenter, S.; Kinzig, A. Resilience, adaptability and transformability in social-ecological systems. Ecol. Soc. 2004, 9. [CrossRef]

9. Rijke, J.; Brown, R.; Zevenbergen, C.; Ashley, R.; Farrelly, M.; Morison, P.; van Herk, S. Fit-for-purpose governance: A framework to make adaptive governance operational. Environ. Sci. Policy 2012, 22, 73-84. [CrossRef]

10. Haasnoot, M.; Kwakkel, J.H.; Walker, W.E.; ter Maat, J. Dynamic adaptive policy pathways: A method for crafting robust decisions for a deeply uncertain world. Glob. Environ. Chang. 2013, 23, 485-498. [CrossRef]

11. Werners, S.; Pfenninger, S.; van Slobbe, E.; Haasnoot, M.; Kwakkel, J.; Swart, R. Thresholds, tipping and turning points for sustainability under climate change. Curr. Opin. Environ. Sustain. 2013, 5, 334-340. [CrossRef]

12. Folke, C.; Hahn, T.; Olsson, P.; Norberg, J. Adaptive governance of social-ecological systems. Annu. Rev. Environ. Resour. 2005, 30, 441-473. [CrossRef]

13. Schlueter, M.; McAllister, R.; Arlinghaus, R.; Bunnefeld, N.; Eisenack, K.; Hoelker, F.; Milner-Gulland, E.; Müller, B.; Nicholson, E.; Quaas, M. New horizons for managing the environment: A review of coupled social-ecological systems modeling. Nat. Resour. Model. 2012, 25, 219-272. [CrossRef]

14. Niemi, G.J.; McDonald, M.E. Application of ecological indicators. Annu. Rev. Ecol. Evol. Syst. 2004, 35, 89-111. [CrossRef]

15. Lavery, S.; Donovan, B. Flood risk management in the thames estuary looking ahead 100 years. Philos. Trans. R. Soc. Lond. A Math. Phys. Eng. Sci. 2005, 363, 1455-1474. [CrossRef] [PubMed]

16. Kwadijk, J.; Haasnoot, M.; Mulder, J.; Hoogvliet, M.; Jeuken, A.; van der Krogt, R.; van Oostrom, N.; Schelfhout, H.; van Velzen, E.; van Waveren, H.; et al. Using adaptation tipping points to prepare for climate change and sea level rise: A case study in the netherlands. Wiley Interdiscip. Rev. Clim. Chang. 2010, 1, 729-740. [CrossRef]

17. Reeder, T.; Ranger, N. How do You Adapt in an Uncertain World? Lessons from the Thames Estuary 2100 Project; World Resources Report Uncertainty Series; World Resources Institute: Washington, DC, USA, 2011. 
18. Gersonius, B.; Ashley, R.; Pathirana, A.; Zevenbergen, C. Climate change uncertainty: Building flexibility into water and flood risk infrastructure. Clim. Chang. 2012, 116, 413-423. [CrossRef]

19. Brown, C.; Werick, W.; Leger, W.; Fay, D. A decision-analytic approach to managing climate risks: Application to the upper great lakes1. J. Am. Water Resour. Assoc. 2011, 47, 524-534. [CrossRef]

20. Poff, N.L.; Brown, C.M.; Grantham, T.E.; Matthews, J.H.; Palmer, M.A.; Spence, C.M.; Wilby, R.L.; Haasnoot, M.; Mendoza, G.F.; Dominique, K.C.; et al. Sustainable water management under future uncertainty with eco-engineering decision scaling. Nat. Clim. Chang. 2016, 6, 25. [CrossRef]

21. Lawrence, J.; Sullivan, F.; Lash, A.; Ide, G.; Cameron, C.; McGlinchey, L. Adapting to changing climate risk by local government in new zealand: Institutional practice barriers and enablers. Local Environ. 2013, 20, 298-320. [CrossRef]

22. Fünfgeld, H. Facilitating local climate change adaptation through transnational municipal networks. Curr. Opin. Environ. Sustain. 2015, 12,67-73. [CrossRef]

23. Hanger, S.; Pfenninger, S.; Dreyfus, M.; Patt, A. Knowledge and information needs of adaptation policy-makers: A european study. Reg. Environ. Chang. 2013, 13, 91-101. [CrossRef]

24. van Slobbe, E.; Werners, S.E.; Riquelme-Solar, M.; Bölscher, T.; van Vliet, M.T.H. The future of the rhine: Stranded ships and no more salmon? Reg. Environ. Chang. 2016, 16, 31-41. [CrossRef]

25. Werners, S.; Swart, R.; van Slobbe, E.; Bölscher, T. Turning points in climate change adaptation. Glob. Environ. Chang. 2013, 16, 253-267.

26. Bölscher, T.; van Slobbe, E.; van Vliet, M.T.; Werners, S.E. Adaptation turning points in river restoration? The rhine salmon case. Sustainability 2013, 5, 2288-2304. [CrossRef]

27. Wardekker, J.A.; de Jong, A.; Knoop, J.M.; van der Sluijs, J.P. Operationalising a resilience approach to adapting an urban delta to uncertain climate changes. Technol. Forecast. Soc. Chang. 2010, 77, 987-998. [CrossRef]

28. Haasnoot, M.; Middelkoop, H.; Offermans, A.; Beek, E.V.; Deursen, W.P.A.V. Exploring pathways for sustainable water management in river deltas in a changing environment. Clim. Chang. 2012, 115, 795-819. [CrossRef]

29. Myers, N.; Mittermeier, R.A.; Mittermeier, C.G.; Da Fonseca, G.A.; Kent, J. Biodiversity hotspots for conservation priorities. Nature 2000, 403, 853-858. [CrossRef] [PubMed]

30. Bekle, H.; Gentilli, J. History of the perth lakes. R. West. Aust. Hist. Soc. 1993, 10, 441-460.

31. Bekle, H. The Wetlands Lost: Drainage of the Perth Lake Systems; Geographical Society of W.A.: Perth, Australia, 1981.

32. Balla, S.A. Wetlands of the Swan Coastal Plain. Volume 1, Their Nature and Management; Water Authority of WA: Perth, Australia, 1993.

33. Conservation Commission of Western Australia. Forrestdale Lake Nature Reserve Management Plan 2005; Management Plan No. 53; Conservation Commission of Western Australia; Government of Western Australia: Perth, Australia, 2005.

34. Storey, A.W.; Vervest, R.M.; Pearson, G.B.; Halse, S.A. Wetlands of the Swan Coastal Plain, Volume 7, Waterbird Usage of Wetlands on the Swan Coastal Plain; Water Authority of WA: Perth, Australia, 1993.

35. Davis, J.A.; Froend, R. Loss and degradation of wetlands in southwestern australia: Underlying causes, consequences and solutions. Wetl. Ecol. Manag. 1999, 7, 13-23. [CrossRef]

36. Barron, O.; Barr, A.; Donn, M. Effect of urbanisation on the water balance of a catchment with shallow groundwater. J. Hydrol. 2013, 485, 162-176. [CrossRef]

37. Department of Water (Ed.) Assessment of the Declining Groundwater Levels in the Gnangara Groundwater Mound, Report hg14; Hydrogeological Record Series; Department of Water: Perth, Australia, 2008.

38. Eamus, D.; Froend, R. Groundwater-dependent ecosystems: The where, what and why of gdes. Aust. J. Bot. 2006, 54, 91-96. [CrossRef]

39. Barron, O.; Froend, R.; Hodgson, G.; Ali, R.; Dawes, W.; Davies, P.; McFarlane, D. Projected risks to groundwater-dependent terrestrial vegetation caused by changing climate and groundwater abstraction in the central perth basin, western australia. Hydrol. Process. 2013, 28, 5513-5529. [CrossRef]

40. Charles, S.; Silberstein, R.; Teng, J.; Fu, G.; Hodgson, G.; Gabrovsek, C.; Crute, J. Climate Analyses for South-West Western Australia; A report to the Australian Government from the CSIRO South-West Western Australia Sustainable Yields Project; CSIRO: 92-92; CSIRO: Canberra, Australia, 2010. 
41. Petrone, K.C.; Hughes, J.D.; Van Niel, T.G.; Silberstein, R.P. Streamflow decline in southwestern australia, 1950-2008. Geophys. Res. Lett. 2010, 37. [CrossRef]

42. Smith, I.; Power, S. Past and future changes to inflows into perth (western australia) dams. J. Hydrol. Reg. Stud. 2014, 2, 84-96. [CrossRef]

43. Froend, R.; Sommer, B. Phreatophytic vegetation response to climatic and abstraction-induced groundwater drawdown: Examples of long-term spatial and temporal variability in community response. Ecol. Eng. 2010, 36, 1191-1200. [CrossRef]

44. Froend, R.H.; Farrelly, C.F.; Wilkins, C.C.; McComb, A.J. Wetlands of the Swan Coastal Plain. Volume 4, the Effects of Altered Water Levels on Wetland Plants; Water Authority of WA: Perth, Australia, 1993.

45. Ali, R.; McFarlane, D.; Varma, S.; Dawes, W.; Emelyanova, I.; Hodgson, G. Potential climate change impacts on the water balance of regional unconfined aquifer systems in south-western australia. Hydrol. Earth Syst. Sci. 2012, 16, 4581-4601. [CrossRef]

46. Sommer, B.; Horwitz, P. Macroinvertebrate cycles of decline and recovery in swan coastal plain (western australia) wetlands affected by drought-induced acidification. Hydrobiologia 2009, 624, 191-203. [CrossRef]

47. Sommer, B.; Froend, R. Resilience of phreatophytic vegetation to groundwater drawdown: Is recovery possible under a drying climate? Ecohydrology 2011, 4, 67-82. [CrossRef]

48. Townley, L.; Turner, J.; Barr, A.D.; Trefry, M. Wetlands of the Swan Coastal Plain Volume 3: Interaction between Lakes, Wetlands and Unconfined Aquifers; Education Department of Western Australia: Perth, Australia, 1993.

49. McFarlane, D. The Effect of Climate Change on South West WA Hydrology; CSIRO: Canberra, Australia, 2012.

50. Australian Bureau of Statistics. 3105.0.65.001-Australian Historical Population Statistics. 2014. Available online: http:/ / abs.gov.au/ausstats (accessed on 8 November 2016).

51. Bureau of meteorology. Bureau of Meteorology, Monthly Rainfall Midland (Perth) 1886-2015, Station Number 9025. Available online: http:/ / www.bom.gov.au/climate/data/index.shtml (accessed on 8 November 2016).

52. Froend, R.; Loomes, R.; Horwitz, P.; Rogan, R.; Lavery, P.; How, J.; Storey, A.; Bamford, M.; Metcalf, B. Study of Ecological Water Requirements on the Gnangara and Jandakot Mounds under Section 46 of the Environmental Protection Act, Task 1: Identification and Re-Evaluation of Ecological Values Prepared for: The Water and Rivers Commission; Water and Rivers Commission, Ed.; Water and Rivers Commission: Perth, Australia, 2004.

53. Eamus, D.; Froend, R.; Loomes, R.; Hose, G.; Murray, B. A functional methodology for determining the groundwater regime needed to maintain the health of groundwater-dependent vegetation. Aust. J. Bot. 2006, 54, 97-114. [CrossRef]

54. Environmental Protection Authority (Ed.) Jandakot Mound Groundwater Resources, Bulletin 1155; Environmental Protection Authority: Perth, Australia, 1992.

55. Semeniuk, C.A. Wetlands of the darling system- a geomorphic approach to habitat classification. J. R. Soc. West Aust. 1987, 69, 95-112.

56. Hill, A.L.; Australia, W.; Australia, W.; Water and Rivers Commission. Wetlands of the Swan Coastal Plain: Wetland Mapping, Classification and Evaluation, Main Report. Volume 2a; Water and Rivers Commission and Department of Environmental Protection: Leederville, WA, USA, 1996.

57. Dawes, W.; Barron, O.; Donn, M.; Pollock, D.; Johnstone, C. Forrestdale Lake Water Balance; CSIRO Water for a Healthy Country National Research Flagship; CSIRO: Perth, Australia, 2009.

58. Froend, R.; Loomes, R.; Horwitz, P.; Bertuch, M.; Storey, M.; Bamford, M. Study of Ecological Water Requirements on the Gnangara and Jandakot Mounds under Section 46 of the Environmental Protection Act, Task 2: Determination of Ecological Water Requirements; Water and Rivers Commission: Perth, Australia, 2004.

59. Canham, C. The Response of Banksia Roots to Change in Water Table Level in a Mediterranean-Type Environment. Ph.D. Thesis, Edith Cowan University, Joondalup, Australia, 2011.

60. Balla, S.; Davis, J. Seasonal variation in the macroinvertebrate fauna of wetlands of differing water regime and nutrient status on the swan coastal plain, western australia. Hydrobiologia 1995, 299, 147-161. [CrossRef]

61. Dale, P.; Knight, J. Wetlands and mosquitoes: A review. Wetl. Ecol. Manag. 2008, 16, 255-276. [CrossRef]

62. Department of Environment and Conservation (Ed.) Treatment and Management of Soils and Water in Acid Sulfate Soil Landscapes; Department of Environment and Conservation: Perth, Australia, 2011.

63. Department of Water (Ed.) Water Information (Win) Database-Time-series Data Site ID 14578 and 12781400; Department of Water, Water Information Section: Perth, Australia, 2015.

64. Jenkinson, A.F. The frequency distribution of the annual maximum (or minimum) values of meteorological elements. Q. J. R. Meteorol. Soc. 1955, 81, 158-171. [CrossRef] 
65. Environmental Protection Authority. Environmental protection act 1986; Environmental Protection Authority: Perth, Australia, 2003.

66. Conservation and Land Management Act. In Conservation and Land Management Act 1984; Government of Western Australia 126 of 1984; State Law Publisher: Perth, Australia, 1984.

67. Wildlife Conservation Act. Wildlife Conservation Act. Wildlife conservation act 1950. In Government of Western Australia 1950, 077 of 1950; (14 \& 15 Geo. VI No. 77); State Law Publisher: Perth, Australia, 1950.

68. Ramsar. The Convention on Wetlands Text, as Amended in 1982 and 1987: The List of Wetlands of International Importance; United Nations Educational, Scientific and Cultural Organization (UNESCO): Paris, France, 2014; pp. 1-47.

69. The Japan Australia Migratory Bird Agreement (JAMBA). Agreement between the government of australia and the government of japan for the protection of migratory birds in danger of extinction and their environment. In Australian Treaty Series; State Law Publisher: Perth, Australia, 1981; No. 6.

70. The China Australia Migratory Bird Agreement (CAMBA). Agreement between the government of australia and the government of the people's republic of china for the protection of migratory birds and their environment. In Australian Treaty Series; State Law Publisher: Perth, Australia, 1988.

71. The Republic of Korea and Australia Migratory Bird Agreement (ROKAMBA). Agreement between the government of australia and the government of the republic of korea on the protection of migratory birds. In Australian Treaty Series; State Law Publisher: Perth, Australia, 2007.

72. Environment Protection and Biodiversity Conservation (EBPC). In Environment Protection and Biodiversity Conservation Act 1999; State Law Publisher: Perth, Australia, 1999.

73. Department of Water (Ed.) Environmental Management of Groundwater from the Jandakot Mound; Triennial Compliance Report to the Office of the Environmental Protection Authority; Department of Water, Government of Western Australia: Perth, Australia, 2012.

74. Zevenbergen, C.; Veerbeek, W.; Gersonius, B.; Van Herk, S. Challenges in urban flood management: Travelling across spatial and temporal scales. J. Flood Risk Manag. 2008, 1, 81-88. [CrossRef]

75. Verdon-Kidd, D.C.; Kiem, A.S.; Moran, R. Links between the Big Dry in Australia and hemispheric multi-decadal climate variability. Hydrol. Earth Syst. Sci. 2014, 18, 2235-2256. [CrossRef]

76. Davis, J.; Brock, M. Detecting unacceptable change in the ecological character of ramsar wetlands. Ecol. Manag. Restor. 2008, 9, 26-32. [CrossRef]

77. Maher, K.; Davis, J. Ecological Character Description for the Forrestdale and Thomsons Lakes Ramsar Site; a Report to the Department of Environment and Conservation; Murdoch University: Perth, Australia, 2009.

78. Froend, R.; Rogan, R.; Loomes, R.; Horwitz, P.; Bamford, M.; Storey, A. Study of Ecological Water Requirements on the Gnangara and Jandakot Mounds under Section 46 of the Environmental Protection Act, Task 3 E 4: Parameter Identification and Monitoring Program Review; Water and Rivers Commission, Ed.; Water and Rivers Commission: Perth, Australia, 2004.

79. Bamford, M.; Bancroft, W.; Raines, J. Effects of Remote Rainfall Events on Waterbird Populations on the Jandakot Mound Wetlands; Department of Water, by Bamford Consulting Ecologists: Perth, Australia, 2010.

80. Capon, S.J.; Lynch, A.J.; Bond, N.; Chessman, B.C.; Davis, J.; Davidson, N.; Finlayson, M.; Gell, P.A.; Hohnberg, D.; Humphrey, C.; et al. Regime shifts, thresholds and multiple stable states in freshwater ecosystems; a critical appraisal of the evidence. Sci. Total Environ. 2015, 534, 122-130. [CrossRef] [PubMed]

81. Sivapalan, M.; Blöschl, G. Time scale interactions and the coevolution of humans and water. Water Resour. Res. 2015, 51, 6988-7022. [CrossRef]

82. Elshafei, Y.; Tonts, M.; Sivapalan, M.; Hipsey, M.R. Sensitivity of emergent sociohydrologic dynamics to internal system properties and external sociopolitical factors: Implications for water management. Water Resour. Res. 2016, 52, 4944-4966. [CrossRef]

83. Ekstrom, J.; Young, O. Evaluating functional fit between a set of institutions and an ecosystem. Ecol. Soc. 2009, 14, 16. [CrossRef]

84. Di Baldassarre, G.; Viglione, A.; Carr, G.; Kuil, L.; Yan, K.; Brandimarte, L.; Blöschl, G. Debates-perspectives on sociohydrology: Capturing feedbacks between physical and social processes. Water Resour. Res. 2015, 51, 4770-4781. [CrossRef]

85. Di Baldassarre, G.; Kooy, M.; Kemerink, J.S.; Brandimarte, L. Towards understanding the dynamic behaviour of floodplains as human-water systems. Hydrol. Earth Syst. Sci. 2013, 17, 3235-3244. [CrossRef] 
86. Hipsey, M.R.; Hamilton, D.P.; Hanson, P.C.; Carey, C.C.; Coletti, J.Z.; Read, J.S.; Ibelings, B.W.; Valesini, F.J.; Brookes, J.D. Predicting the resilience and recovery of aquatic systems: A framework for model evolution within environmental observatories. Water Resour. Res. 2015, 51, 7023-7043. [CrossRef]

87. Hallegatte, S. Strategies to adapt to an uncertain climate change. Glob.Environ. Chang. 2009, 19, $240-247$. [CrossRef]

88. Mitchell, B.; Hollick, M. Integrated catchment management in western australia: Transition from concept to implementation. Environ. Manag. 1993, 17, 735-743. [CrossRef]

89. Davis, J.; O'Grady, A.P.; Dale, A.; Arthington, A.H.; Gell, P.A.; Driver, P.D.; Bond, N.; Casanova, M.; Finlayson, M.; Watts, R.J.; et al. When trends intersect: The challenge of protecting freshwater ecosystems under multiple land use and hydrological intensification scenarios. Sci. Total Environ. 2015, 534, 65-78. [CrossRef] [PubMed]

90. Nelson, D.R.; Adger, W.N.; Brown, K. Adaptation to environmental change: Contributions of a resilience framework. Annu. Rev. Environ. Resour. 2007, 32, 395-419. [CrossRef]

(C) 2018 by the authors. Licensee MDPI, Basel, Switzerland. This article is an open access article distributed under the terms and conditions of the Creative Commons Attribution (CC BY) license (http://creativecommons.org/licenses/by/4.0/). 